\title{
Long-term follow-up of an 8-year-old boy with insulinoma as the first manifestation of a familial form of multiple endocrine neoplasia type 1
}

\author{
Seguimento de longo prazo em um menino de 8 anos \\ de idade com insulinoma como primeira manifestação \\ de neoplasia endócrina múltipla tipo 1
}

${ }^{1}$ Center for Molecular Biology and Genetic Engineering (CBMEG), Universidade Estadual de Campinas (Unicamp), Campinas, SP, Brazil ${ }^{2}$ Department of Pediatrics, Faculdade de Ciências Médicas (FCM), Unicamp, Campinas, SP, Brazil ${ }^{3}$ Department of Clinical Medicine, FCM-Unicamp, Campinas, SP, Brazil

${ }^{4}$ Department of Pathology Anatomy, FCM-Unicamp, Campinas, SP, Brazil

Correspondence to:

Gil Guerra-Júnior

Departamento de Pediatria,

FCM-Unicamp

13083-887 - Campinas, SP, Brazil gilguer@fcm.unicamp.br

Received on Jul/29/2010

Accepted on Nov/18/2010
Helena Campos Fabbri', Maricilda Palandi de Mello', Fernanda Caroline Soardi', Adriana Mangue Esquiaveto-Aun 1,2, Daniel Minutti de Oliveira ${ }^{3}$, Fernanda Canova Denardi ${ }^{3}$, Arnaldo Moura-Neto ${ }^{3}$, Heraldo Mendes Garmes ${ }^{3}$, Maria Tereza Matias Baptista ${ }^{3}$, Patrícia Sabino de Matos ${ }^{4}$, Sofia Helena Valente de Lemos-Marini², Lilia Freire Rodrigues D'Souza-Li², Gil Guerra-Júnior ${ }^{2}$

\section{SUMMARY}

Multiple endocrine neoplasia type 1 (MEN1) is an autosomal dominant hereditary cancer syndrome characterized mostly by parathyroid, enteropancreatic, and anterior pituitary tumors. We present a case of an 8-year-old boy referred because of hypoglycemic attacks. His diagnosis was pancreatic insulinoma. Paternal grandmother died due to repeated gastroduodenal ulcerations and a paternal aunt presented similar manifestations. At a first evaluation, the father presented only gastric ulceration but subsequently developed hyperparathyroidism and lung carcinoid tumor. During almost 15 years of follow-up, three brothers and the index case presented hyperparathyroidism and hyperprolactinemia. Molecular study showed a $\mathrm{G}$ to $A$ substitution in intron 4 , at nine nucleotides upstream of the splicing acceptor site, causing a splicing mutation. All affected members of the family have the same mutation. Paternal grandmother and aunt were not studied and the mother does not carry any mutation. MEN1 is a rare condition that requires permanent medical assistance. Early clinical and genetic identification of affected individuals is essential for their own surveillance and also for genetic counseling. Arq Bras Endocrinol Metab. 2010;54(8):754-60

\section{SUMÁRIO}

A neoplasia endócrina múltipla tipo 1 (NEM1) é uma doença hereditária autossômica dominante, caracterizada principalmente por tumores de paratireoide, enteropancreáticos e adeno-hipofisários. Apresentamos o caso de um menino com 8 anos encaminhado por crises de hipoglicemia. Seu diagnóstico foi insulinoma pancreático. Sua avó paterna faleceu por úlceras gastroduodenais de repetição e a tia paterna tinha as mesmas manifestações. Na primeira avaliação, o pai apresentou apenas úlcera gástrica, porém com a evolução desenvolveu hiperparatireoidismo e tumor carcinoide pulmonar. Durante cerca de 15 anos de seguimento, os três irmãos e o caso índice desenvolveram hiperparatireoidismo e hiperprolactinemia. 0 estudo molecular mostrou a substituição $\mathrm{G}$ por $\mathrm{A}$ no intron 4, a nove nucleotídeos do sítio aceptor de splicing, criando um novo sítio de splicing. Todos os membros da família afetados e estudados tinham a mesma mutação. A NEM1 é uma condição rara que requer assistência médica permanente. As identificações clínicas e genéticas precoces são essenciais para o tratamento e aconselhamento genético. Arq Bras Endocrinol Metab. 2010;54(8):754-60 


\section{INTRODUCTION}

M ultiple endocrine neoplasia type l (MENl OMIM 131100) is an autosomal dominant familial cancer syndrome characterized by primary hyperparathyroidism in association with endocrine enteropancreatic tumors and anterior pituitary adenomas, but manifestations of carcinoid tumors, adrenal adenomas, and lipomas are also reported. The occurrence of two MEN1-related endocrine tumors is sufficient to establish the clinical diagnosis (1-3). This syndrome often occurs at a young age with equal sex distribution (3). Primary hyperparathyroidism is responsible for more than $90 \%$ of clinical cases and usually it is the first clinical manifestation of MEN1. Enteropancreatic tumors (gastrinomas, glucagonomas, VIPomas, insulinomas, or non-functioning tumors) affect about $30 \%-80 \%$ of patients (4), while the incidence of pituitary adenomas (prolactinomas, somatotropinomas, corticotropinomas, or non-functioning tumors) in MENl patients varies from $15 \%$ to $90 \%$ (5-6).

The MENI gene, which is responsible for the disease, is located on $1 \mathrm{lql} 3$, occupies $9.8 \mathrm{~kb}$ of genomic DNA, and encodes a 610-aminoacid protein called menin, within 10 exons (7). It is considered to be a tumor suppressor gene by altering JunD-mediated transcription (8). It is involved in the regulation of cell functions such as DNA replication and repair, and also in the transcriptional machinery $(7,9,10)$. MEN1 mutations have a high degree of penetrance: more than $95 \%$ of patients who carry a mutation will develop the disease by the fifth decade of life (3), however, the phenotype is highly variable therefore a direct genotype-phenotype correlation has been difficult to be established (11). Carriers of MENl gene mutations may benefit from periodic clinical evaluations (12). Generally, MENI germline mutations are identified with a prevalence average of $70 \%$ in the familial forms, whereas the sporadic cases, associated with de novo mutation in the MENI gene, represents about 5\%-10\% (13). More than 1,000 MEN1 mutations have been reported; about $25 \%$ are nonsense, $45 \%$ intragenic deletions, $15 \%$ insertions, $10 \%$ missense mutations, and less than $5 \%$ are splice site mutations (14).

Herein we report an unusual index case presenting with hypoglycemia in early age ( 8 years of age) within a MEN1 family. Long-term follow-up with clinical manifestations and management of all affected relatives are also discussed.

\section{CASE REPORT}

\section{Clinical data}

An 8-year-old boy was admitted at our pediatric clinic because of seizures misdiagnosed as epilepsy (normal EEG and cerebral CT). He also had sweating, palpitation, tremulousness, hunger, anxiety, and a sudden weight gain (8 kg in 4 months). Laboratory data confirmed hyperinsulinemic hypoglycemia $($ glycemia $=19$ $\mathrm{mg} / \mathrm{dL}-$ Normal range $-\mathrm{NR}=60-99$; insulinemia $=$ $26.2 \mathrm{IU} / \mathrm{mL}-\mathrm{NR}<5$; and C-peptide $=3.2 \mathrm{ng} / \mathrm{mL}-$ $\mathrm{NR}=1.1-5.0)$. Pancreatic angiography and abdomen CT suggested nodules in the pancreas region. Upon intraoperative ultrasound two lesions in the distal body of the pancreas were observed $(0.6 \mathrm{~cm}$ and $0.3 \mathrm{~cm}$ in size); they were removed by partial pancreatectomy. Histological analysis confirmed insulinoma, and immunohistochemistry examination was also strongly positive for insulin but also slightly positive for glucagon and gastrin (Figure 1 A-D).

To date, his family history includes a healthy mother and 3 brothers (an older boy and two younger twins). In addition, his paternal grandmother had repeated gastroduodenal ulceration and urolithiasis since the age of 38 and died at the age of 45 due to gastric ulcer perforation. Autopsy showed peptic ulcer with gastrin-secreting duodenal mucosa tumor (gastrinoma - Zollinger-Ellison syndrome) and primary hyperparathyroidism. His paternal aunt also had repeated gastroduodenal ulceration and urolithiasis, and his father presented only gastroduodenal ulceration when he was first examined.

The patient had been clinically stable during several years of follow-up and showed normal growth and puberty. However, at the age of 16 he also presented elevated PTH $(90.9 \mathrm{pg} / \mathrm{mL}, \mathrm{NR}=10.0-50.0)$ and calcium $(11.1 \mathrm{mg} / \mathrm{dL}-\mathrm{NR}=8.5-10.5)$ leading to primary hyperparathyroidism diagnosis and subsequently to subtotal parathyroidectomy. He is now 25 years old, without symptoms, MRI of the pituitary region is nor$\mathrm{mal}$ and prolactin high $(54.3 \mathrm{ng} / \mathrm{mL}-\mathrm{NR}<15)$; PTH and calcium serum concentrations have been maintained in the upper normal range throughout 5 years; and, both glycemia and insulin are normal.

During 15 years of family follow-up, his father showed primary hyperparathyroidism. In the preoperative evaluation for subtotal parathyroidectomy a bronchial carcinoid tumor was identified in the chest radiography. Both tumors were surgically treated and 

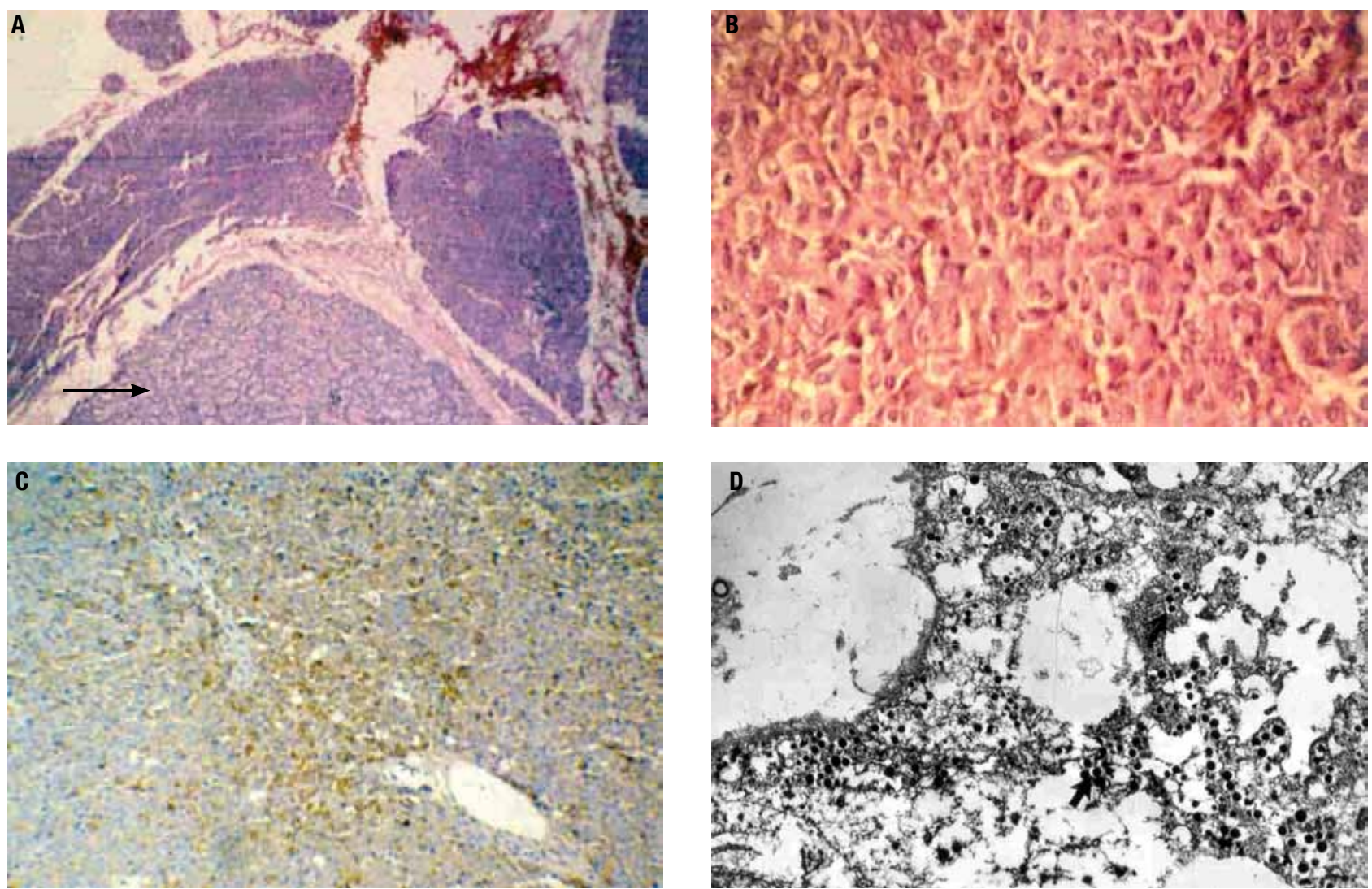

Figure 1. (A) HE-50X: The arrow indicates a hypercellular pancreatic nodule with thin capsule. (B) HE-400X: Polygonal cells in a solid, trabecular and glandular pattern, with no atypia or necrosis. (C) Immunohistochemical assay demonstrating intense and diffuse positivity for insulin. (D) Ultrastructural study showing neuroendocrine granules.

chemotherapy was performed after lobectomy. He is now $5 \mathrm{l}$ years old and is doing well with normal serum levels of PTH, calcium, glucose, insulin and prolactin.

A 29-year-old brother reported hyperprolactinemia due to a pituitary macroadenoma when he was 24 years old. Since then he has been successfully treated with cabergoline. One year later, he developed primary hyperparathyroidism; therefore, he underwent subtotal parathyroidectomy. The two 23-year-old younger twin brothers presented different symptoms. One developed hyperinsulinemic hypoglycemia due to insulinoma at the age of 18 and underwent subtotal pancreatectomy. Histological analysis confirmed multiple pancreatic nodules and immunohistochemistry examination was positive for insulin and negative for glucagon and gastrin. One year later, he developed diabetes and started insulin replacement. At the age of 20 , he had hyperprolactinemia that was treated with cabergoline and after other year he showed elevated PTH and calcium indicating subtotal parathyroidectomy. The other twin had elevated PTH and calcium when he was 18 years old; therefore subtotal parathyroidectomy was performed.
Two years later he presented hyperprolactinemia treated with cabergoline. Father and brothers remain under treatment and periodic screening, which consists of medical appointments taking place twice a year, laboratorial investigation performed annually and imaging studies conducted every two years (Table 1 ).

\section{Molecular analysis}

Blood specimens of the patient and his relatives were collected with approval by the appropriate institutional review board and a signed informed consent was obtained.

Genomic DNA from peripheral blood leukocytes was purified by proteinase $\mathrm{K}$ digestion and phenol/ chloroform extraction followed by ethanol precipitation using standard techniques (15). The 10 exons and the exon-intron junction regions of the MENI gene were PCR-amplified from genomic DNA with specific primers designed using GenRunner free software (Table 2). MENI gene sequence was obtained in the ENSEMBL database (ENSG00000133895 - www.ensembl.org). 
Table 1. Clinical data, management and follow-up of MEN1 manifestations in all cases of the Brazilian family studied

\begin{tabular}{|c|c|c|c|c|c|}
\hline Patient & Manifestation & $\begin{array}{c}\text { Age at } \\
\text { diagnosis }\end{array}$ & Management & Follow-up & $\begin{array}{l}\text { Time of } \\
\text { follow-up }\end{array}$ \\
\hline \multirow[t]{3}{*}{ Index case } & Hypoglycemia (insulinoma) & 8 & Partial pancreatectomy & Normal insulin and glycemia & 17 \\
\hline & Primary hyperparathyroidism & 16 & Subtotal parathyroidectomy & Upper normal range of PTH and calcium & \\
\hline & Hyperprolactinemia (normal MRI) & 25 & Observation & Moderate hyperprolactinemia & \\
\hline Paternal grandmother & $\begin{array}{l}\text { Repeated gastroduodenal } \\
\text { ulceration and urolithiasis }\end{array}$ & 38 & NR & $\begin{array}{l}\text { Died at } 45 \text { years-old due to gastric } \\
\text { perforation (gastrinoma) }\end{array}$ & - \\
\hline Paternal aunt & $\begin{array}{l}\text { Repeated gastroduodenal } \\
\text { ulceration and urolithiasis }\end{array}$ & NR & NR & NR & NR \\
\hline \multirow[t]{3}{*}{ Father } & Gastroduodenal ulceration & 35 & Clinical treatment & Without symptoms & 17 \\
\hline & Primary hyperparathyroidism & 45 & Subtotal parathyroidectomy & Normal PTH and calcium & \\
\hline & Bronchial carcinoid & 45 & Lobectomy + chemotherapy & Without symptoms & \\
\hline \multirow[t]{2}{*}{ Older brother } & $\begin{array}{l}\text { Hyperprolactinemia } \\
\text { (macroadenoma) }\end{array}$ & 24 & Cabergoline treatment & Normal prolactin & 5 \\
\hline & Primary hyperparathyroidism & 25 & Subtotal parathyroidectomy & Normal PTH and calcium & \\
\hline \multirow[t]{3}{*}{ Younger brother (twin A) } & Hypoglycemia (insulinoma) & 18 & Near-total pancreatectomy & Insulin-dependent diabetes & 5 \\
\hline & Hyperprolactinemia (normal MRI) & 20 & Cabergoline treatment & Normal prolactin & \\
\hline & Primary hyperparathyroidism & 21 & Subtotal parathyroidectomy & Normal PTH and calcium & \\
\hline \multirow[t]{2}{*}{ Younger brother (twin B) } & Primary hyperparathyroidism & 18 & Subtotal parathyroidectomy & Normal PTH and calcium & 5 \\
\hline & Hyperprolactinemia (normal MRI) & 20 & Cabergoline treatment & Normal prolactin & \\
\hline
\end{tabular}

NR: not reported.

Table 2. Primers designed for amplification and sequencing of MEN1 gene

\begin{tabular}{|c|c|c|c|}
\hline Primer & Sequence (5'-3') & $\operatorname{Tm}\left({ }^{\circ} \mathrm{C}\right)^{1}$ & Size $(b p)^{2}$ \\
\hline 5'UTRs & CCCCGAGTCTGCAGGTAGTG & 61.8 & 801 \\
\hline Ex 2as & AGCTCGGCAGCAAACAGG & 60.6 & 801 \\
\hline Int 1s & AACCTTAGCGGACCCTGGG & 63 & 705 \\
\hline Int 2as & GCATATCATTTCCCCTCTCTGG & 62.4 & 705 \\
\hline $\operatorname{lnt} 2 \mathrm{~s}$ & CCCCATGTTAAAGCACAGAGG & 61.6 & 720 \\
\hline Int 4as & ACTAACCCATTTTTCCAGGAGG & 61.6 & 720 \\
\hline $\operatorname{lnt} 4 \mathrm{~s}$ & СTTTCCСTTCCTGAGCTTCAG & 60.3 & 596 \\
\hline Int 6as & ACACAAAGTGAGACTGGATGGG & 60.4 & 596 \\
\hline $\operatorname{lnt} 6 \mathrm{~s}$ & TGGGAGTGGAGATGGAGAGG & 60.6 & 956 \\
\hline Int 8as & ATCCCTAATCCCGTACATGCAG & 58 & 956 \\
\hline $\operatorname{lnt} 7 s^{3}$ & TCСТTTCTTCСССТССАТСAG & 62.4 & \\
\hline Int $7 a s^{3}$ & ACTGGATGGAAAGGGGATG & 58 & \\
\hline Int 8s & CTGGCTATGGATTGGCTTTATA & 59.4 & 486 \\
\hline Int 9as & AGCAAGGTGAGAGCAAGGTTG & 61.2 & 486 \\
\hline $\operatorname{lnt} 9 \mathrm{~s}$ & TGGGTGGGATGGGATGG & 60.1 & 711 \\
\hline 3'UTRas & AGGGTTTGGGTAGAGGTGAGG & 61.6 & 711 \\
\hline Ex $10 s^{3}$ & ACTGGACAAGGGCCTGGG & 61.3 & \\
\hline Ex 10as ${ }^{3}$ & AGTTGCAGCTTGATGGCG & 58.7 & \\
\hline
\end{tabular}

: : annealing temperature used in PCR; ${ }^{2}$ : size of amplified fragments; ${ }^{\text {: }}$ internal primers used for sequencing purposes.

All coding regions and their adjacent sequences of the MENI gene from the four brothers and their parents were amplified and sequenced. The molecular analyses identified the heterozygous $\mathrm{G}>\mathrm{A}$ nucleotide change in the splice acceptor region of intron 4 (IVS4$9 \mathrm{G}>\mathrm{A}$ ) in all brothers and the father (Figure $2 \mathrm{~A}-\mathrm{C}$ ). The mother did not carry the mutation; and the paternal grandmother and aunt were not tested. Heterozygosis for single nucleotide polymorphisms (SNPs) were identified as described in table 3 .

\section{DISCUSSION}

Clinical manifestations of MENl-associated diseases are very rare in childhood (14) and the overall prevalence of insulinoma is almost 10\% (3). Primary hyperparathyroidism is the most common endocrinopathy in MEN1, reaching nearly $100 \%$ penetrance by the age of 50 years (3). Urolithiasis is usually the first manifestation of hyperparathyroidism associated with MENl and it affects about $30 \%$ to $75 \%$ of the cases (16).

In the present paper, MENl-associated insulinoma was first suspected based on the familial history of paternal grandmother and aunt, and was confirmed after histological analysis. Genetic testing is strongly recommended in familial cases of Zollinger-Ellison syndrome since they are almost exclusively seen in MENl patients (17). In the family reported here, genetic testing showed that the father and all siblings were carriers of the IVS4-9G>A mutation. The long-term follow-up of 

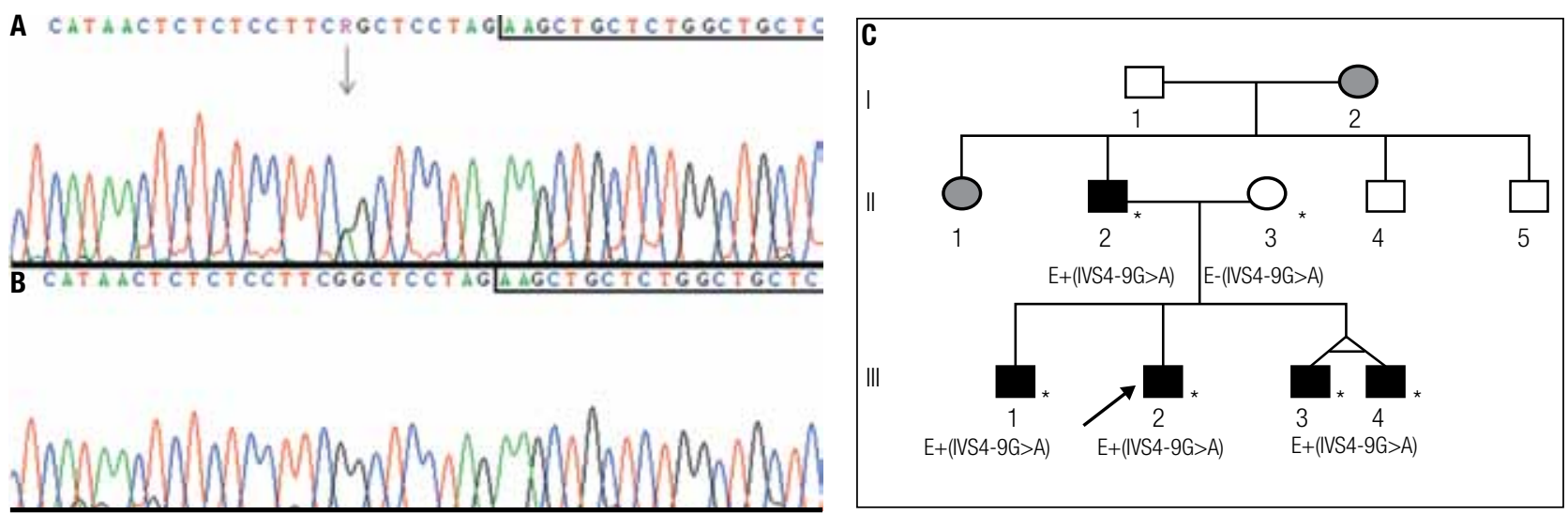

Figure 2. Sequence analysis showing the IVS4-9G>A mutation. Sequences boxed correspond to the first nucleotides of exon 5 and the arrow indicates the nucleotide change. (A) Heterozygous $G$ to A substitution detected in blood DNA of the patient. (B) DNA from his normal mother. (C) Family pedigree. The arrow indicates the index-case. Asterisks indicate individuals that were personally analyzed. $E+($ IVS4-9G>A) and E-(IVS4-9G>A) denote that the individuals have been molecularly evaluated for the mutation and are, respectively, heterozygous and normal homozygous. Individuals I.2 and II. 1 were not molecularly analyzed but clinical data indicated MEN1 manifestation.

Table 3. Heterozygosis for SNPs and c.799-9G>A mutation in MEN1 family

\begin{tabular}{|c|c|c|c|c|}
\hline & 5'UTR & Intron 4 & Exon 9 & Intron 9 \\
\hline SNP access number & rs679946 & mutation & rs2071313 & rs654440 \\
\hline cDNA position & c. $-35 A>C>T$ & c.799-9G>A & c. $1269 C>T$ & $C .1365+103 C>G$ \\
\hline$\|-2$ & $A / T$ & G/A & $\mathrm{C} / \mathrm{T}$ & C/G \\
\hline$\|-3$ & $\mathrm{~T} / \mathrm{T}$ & $G / G$ & $\mathrm{C} / \mathrm{C}$ & $\mathrm{C} / \mathrm{C}$ \\
\hline|| $\mid-1$ & $T / \mathbf{C}$ & $\mathrm{G} / \mathbf{A}$ & $\mathrm{C} / \mathbf{T}$ & $\mathbf{C} / \mathbf{G}$ \\
\hline|| $\mid-2$ & $\mathrm{~T} / \mathrm{T}$ & $G / A$ & $\mathrm{C} / \mathrm{C}$ & $\mathrm{C} / \mathrm{C}$ \\
\hline|| $\mid-3$ & $T / T$ & $\mathrm{G} / \mathbf{A}$ & $\mathrm{C} / \mathrm{C}$ & $\mathrm{C} / \mathrm{C}$ \\
\hline|| $\mid-4$ & $T / \mathbf{C}$ & $G / A$ & $\mathrm{C} / \mathbf{T}$ & C/G \\
\hline
\end{tabular}

all affected members showed variable clinical manifestations, with early onset (from 8 to 24 years of age) in all the brothers.

Among enteropancreatic tumors, gastrinomas are the most common and the major cause of morbidity and mortality, as occurred in the paternal grandmother. They are often multiple and present high risk of metastasis. Conversely, insulinomas are usually benign and surgery tends to be curative (18). Non-functional enteropancreatic tumors may appear in the first two decades of life and present risk of malignancy. Medical conduct already recommends to begin screening for enteropancreatic tumors, especially for insulinoma, at the age of 5 years $(3,18)$. Nowadays, this recommendation has been extended to the non-functioning tumors as well (4).

To our knowledge, this is the second report describing clinical symptoms and genetic testing in twins with MEN1. Similarly to the case reported by Rix and cols. (19), the twin brothers presented different phenotypes, with primary hyperparathyroidism and hyperprolac- tinemia in both, but only one developed insulinoma. Variability in phenotypes may reflect a random chance for a second mutation in susceptible cells with loss of heterozygosity, in accordance with Knudson's “two hit" hypothesis $(7,14)$. Some of the affected individuals described here are heterozygous for frequent SNPs in MEN1 gene. The p.D418D polymorphism caused by the c.1269C>T nucleotide change in exon 9 was found in the father and in individuals III-1 and III-4. This polymorphism has previously been associated with sporadic hyperparathyroidism $(20)$ and it was found to be more frequent in Brazilian patients than in those studied in the USA and Europe (21). In the present study hyperparathyroidism was diagnosed in five affected individuals but only three carry the p.D418D polymorphism, therefore it seems that hyperparathyroidism and p.D418D are not associated in those cases. Whereas, other polymorphisms have been identified (Figure 1D), if combined to specific haplotypes we found that the "TACC" haplotype (c.-35A>T>C, c.799-9G>A, 
c. $1269 \mathrm{C}>\mathrm{T}$, and $\mathrm{c} .1365+103 \mathrm{C}>\mathrm{G}$ ) is present in the individuals who developed insulinoma. Two other haplotypes were identified: "CAGT" in two brothers and probably "TATG" in the father. Since all siblings carry the IVS4-9G>A mutation inherited from the father, it is very difficult to find an explanation for such differences within the MENI gene. Possible mechanisms might involve double independent events generating germline mosaicism.

In late onset heritable disorders, the benefits of genetic diagnosis must be balanced with the psychological effects of the screening procedure. As no curative treatment can be offered to carriers of MENI gene mutations, early detection will be positive for the possibility of initiating adequate treatment at a presymptomatic stage, which may decrease morbidity and mortality $(12,21,22)$. Therefore, parents within families with a clinical diagnosis of MENl should receive genetic counseling in order to be able to decide about genetically testing their children.

The earliest presentation of an endocrine tumor in MENl reported in the literature was an aggressive prolactin and GH-secreting pituitary macroadenoma in a 5 -year-old boy (23). Pancreatic insulinoma has been described in a 7-year-old boy (24), followed by primary hyperparathyroidism at the age of 8 years (3). Our index patient showed an insulinoma when he was 8 years old, reinforcing the proposition that a clinical screening program for children carrying $M E N I$ gene mutations should start at the age of 10-15 years $(21,22,25,26)$. These children should be evaluated with annual blood tests by measuring serum calcium, pancreatic polypeptide and gastrin, prolactin and insulin-like growth factor-1. Annual pancreatic ultrasound, and pancreatic and pituitary MRI every 3-5 years, should also be performed. A consensus statement from 2001 (3) recommended that screening should begin at 5 years of age as mentioned above.

Several germline MENI gene mutations have been described in Brazilian patients $(21,27)$ and they are mainly frameshift, nonsense or missense mutations. The $\mathrm{G}>\mathrm{A}$ substitution at 9 nucleotides upstream from the splicing junction of the MENI gene in intron 4, described before in European and Japanese patients $(28,29)$, is reported here for the first time in a Brazilian family. The IVS4-9G>A that was first described as a polymorphism with heterozygosity frequency of $3 \%$ (30), however, it was further demonstrated to produce two different transcripts. The most abundant transcript presented an insertion of seven nucleotides in the exon 4 and 5 junction, and the less abundant had a normal mRNA sequence (29). Therefore, it was associated to MENl phenotype in an European adult patient with adrenocortical adenoma and lung carcinoid tumor (28) and also in three Japanese adult patients from two unrelated families, but with different phenotypes. The different phenotypes were: one with hyperparathyroidism, repeated gastroduodenal ulceration, subcutaneous lipoma and insulinoma; the other two sisters presented hyperparathyroidism, whereas only one had insulinoma (29). Our index case also had insulinoma and hyperparathyroidism, however, the manifestations were observed earlier than those previously reported. In all cases this alteration was described as a germline mutation.

In conclusion, the early diagnose and the long-term follow-up of the MENl family described in the present paper reinforces that careful family history with regards to familial MENl should always be investigated in patients presenting with insulinoma in childhood. Additionally, the possibility of confirming MENl diagnosis by genetic testing should be offered to the children and their families.

Acknowledgements: The authors would like to thank Dr. Márcio José da Silva from the sequencing facility. We also thank Dr. Luciana de Campos Leite Medeiros and Mrs. Mara Sanches Guaragna for reading the manuscript.

Disclosure: no potential conflict of interest relevant to this article was reported.

\section{REFERENCES}

1. Carling T. Multiple endocrine neoplasia syndrome: genetic basis for clinical management. Curr Opin Oncol. 2005;17:7-12.

2. Guang-Wen Z, Yao W, Xi C, Xiao-Hua J, Xiao-Ying L, Guang N, et al. Diagnosis and surgical treatment of multiple endocrine neoplasia. Chin Med J. 2009;122:1495-500.

3. Brandi ML, Gagel RF, Angell A, Bilczikian JP, Beck-Peccoz P, Bordi $C$, et al. Consensus: guidelines for diagnosis and therapy of MEN type 1 and type 2. J Clin Endocrinol Metab. 2001;86:5658-71.

4. Newey PJ, Jeyabalan J, Walls GV, Christie PT, Gleeson FV, Gould $\mathrm{S}$, et al. Nonfunctioning tumors in children with MEN1. J Clin Endocrinol Metab. 2009;94:3640-6.

5. Corbetta S, Pizzocaro A, Peracchim, Beck-Peccoz P, Faglia G, Spada A. Multiple endocrine neoplasia type 1 in patients with recognized pituitary tumours of different types. Clin Endocrinol. 1997;47:507-12.

6. Yoshimoto K, Saito S. Clinical characteristics in multiple endocrine neoplasia type 1 in Japan: a review of 106 patients. Nippon Naibunpi Gakkai Zasshi. 1991;67:764-74.

7. Marx SJ, Spiegel AM, Skarulis MC, Doppman JL, Collins PS, Liotta LA. Multiple endocrine neoplasia type 1: clinical and genetic topics. Ann Intern Med. 1998;129:484-94. 
8. Chandrasckharappa SC, Guru SC, Manickan P, Olufemi SE, Collins PS, Emmert-Buck MR, et al. Positional cloning of the gene for multiple endocrine neoplasia-type 1. Science. 1997;276:404-7.

9. Franchi GM, Villa VV, Carrera P, Sartorio SM, Maffi P, Bosi E, et al. A new mutation in the MEN1 gene. Cancer Genet Cytogenet. 2009;192:199-01.

10. Kim H, Lee JR, Cho EJ, Liu JO, Youn HD. Menin, a tumor suppressor, represses JunD-mediated transcriptional activity by association with mSIn3A-histonic deacctylase complex. Cancer Res. 2003;63:6135-9.

11. Falchetti A, Marini F, Brandi ML. Multiple endocrine neoplasia. GeneReviews 2010. Available at: http://www.ncbi.nlm.nih.gov/bookshelf/br.fcgi?book=gene\&part=men1. Accessed at: 27 Jul 2010.

12. Geerdink BAM, Van der Luijt RB, Lips CJM. Do patients with multiple endocrine neoplasia syndrome type 1 benefit from periodical screening? Eur J Endocrinol. 2003;149:577-82.

13. Falchetti A, Brandi ML. Multiple endocrine neoplasia type I variants and phenocopies: more than a nosological issue? J Clin Endocrinol Metab. 2009;94:1518-20.

14. Marx SJ, Nieman LK. Aggressive pituitary tumours in MEN1: do they refute the two-hit model of tmorigenesis? J Clin Endocrinol Metab. 2002;87:453-6.

15. Sambrook J, Fritsch EF, Maniatis TE. Molecular cloning, a laboratory manual. New York: Cold Spring Harbor; 1989.

16. Lourenço Jr DM, Coutinho FL, Toledo RA, Montenegro FL, Correia-Deur JE, Toledo SP. Early-onset, progressive, frequent, extensive, and severe bone mineral and renal complications in multiple endocrine neoplasia type 1-associated primary hyperparathyroidism. J Bone Miner Res. 2010;25(11):2382-91.

17. Ruszniewski P, Fave GD, Cadiot G, Komminoth P, Chung D, Kos-Kudla B. Well-differentiated gastric tumors/carcinomas. Neuroendocrinology. 2006;84:158-64.

18. Schussheim DH, Skarulis MC, Agarwal SK, Simonds WF, Burns AL, Spiegel AM, et al. Multiple endocrine neoplasia type 1: new clinical and basic findings. Trends Endocrinol Metab. 2001;12:173-8.

19. Rix M, Hertel NT, Nielsen FC, Jacobsen BB, Hoejberg AS, Brixen $\mathrm{K}$, et al. Cushing's disease in childhood as the first manifestation of multiple endocrine neoplasia syndrome type 1. Eur J Endocrinol. 2004;151:709-15.
20. Correa P, Lundgren E, Rastad J, Åkerström G, Westin G, Carling T. Multiple endocrine neoplasia type 1 polymorphism D418D is associated with sporadic primary hyperparathyroidism. Surgery. 2002;132:450-5.

21. Toledo RA, Lourenço DM, Coutinho FL, Quedas E, Mackowiack I, Machado MC, et al. Novel MEN1 germline mutations in Brazilian families with multiple endocrine neoplasia type 1. Clin Endocrinol. 2007;67:377-84.

22. Lourenço Jr DM, Toledo RA, Coutinho FL, Margarido LC, Siqueira $\mathrm{SA}$, dos Santos MA, et al. The impact of clinical and genetic screenings on the management of the multiple endocrine neoplasia type 1. Clinics (Sao Paulo). 2007;62:465-76.

23. Stratakis CA, Shussheim DH, Freedman SM, Keil MF, Pack SD, Agarwal SK, et al. Pituitary macroadenoma in 5-year-old: an early expression of multiple endocrine neoplasia type 1. J Clin Endocrinol Metab. 2000;85:4776-80.

24. Kontogeorgos G, Kapranos N, Tzavara I, Thalassinos N, Rologis D. Monossomy of chromosome 11 in pituitary adenoma in a patient with familial multiple endocrine neoplasia type 1. Clin Endocrinol. 2001;54:117-20.

25. Johnston LB, Chew SL, Trainer PJ, Reznck R, Grossman AB, Besser GM, et al. Screening children at risk of developing inherited endocrine neoplasia syndromes. Clin Endocrinol. 2000;52:127-36.

26. Johnston LB, Chew SL, Lowe D, Reznck R, Monsom JP, Savage $\mathrm{MO}$. Investigating familial endocrine neoplasia syndromes in children. Horm Res. 2001;55:31-5.

27. Lourenço Jr DM, Toledo RA, Mackowiak II, Coutinho FL, Cavalcanti MG, Correia-Deur JE, et al. Multiple endocrine neoplasia type 1 in Brazil: MEN1 founding mutation, clinical features, and bone mineral density profile. Eur J Endocrinol. 2008;159:259-74.

28. Görtz B, Roth J, Speel EJM, Krähemmann A, De Krieger RR, Matias-Guiu $X$, et al. MEN1 gene mutation analysis of sporadic adrenocortical lesions. Int J Cancer. 1999;80:373-9.

29. Kishi M, Tsukada T, Shimizu S, Hosono K, Ohkubo T, Kosuge T, et al. A novel splicing mutation (894-9 G-A) of the MEN1 gene responsible for multiple endocrine neoplasia type 1. Cancer Letters. 1999;142:105-110.

30. Bassett JH, Forbes SA, Pannett AA, Lloyd SE, Christie PT, Wooding $C$, et al. Characterization of mutations in patients with multiple endocrine neoplasia type 1. Am J Hum Genet 1998;62:232-44. 